\title{
BMJ Open Development of evidence-based Australian medication-related indicators of potentially preventable hospitalisations: a modified RAND appropriateness method
}

\author{
Gillian E Caughey, ${ }^{1}$ Lisa M Kalisch Ellett, ${ }^{1}$ Te Ying Wong ${ }^{2}$
}

To cite: Caughey GE, Kalisch Ellett LM, Wong TY. Development of evidencebased Australian medicationrelated indicators of potentially preventable hospitalisations: a modified RAND appropriateness method. BMJ Open 2014;4: e004625. doi:10.1136/ bmjopen-2013-004625

- Prepublication history for this paper is available online. To view these files please visit the journal online (http://dx.doi.org/10.1136/ bmjopen-2013-004625).

Received 4 December 2013 Revised 17 March 2014 Accepted 1 April 2014

CrossMark

For numbered affiliations see end of article.

Correspondence to Dr Lisa Kalisch Ellett; lisa.kalisch@unisa.edu.au

\section{ABSTRACT}

Objective: Indicators of potentially preventable hospitalisations have been adopted internationally as a measure of health system performance; however, few assess appropriate processes of care around medication use, that if followed may prevent hospitalisation. The aim of this study was to develop and validate evidence-based medication-related indicators of potentially preventable hospitalisations. Setting: Australian primary healthcare.

Participants: Medical specialists, general practitioners and pharmacists. A modified RAND appropriateness method was used for the development of medicationrelated indicators of potentially preventable hospitalisations, which included a literature review, assessment of the strength of the supporting evidence base, an initial face and content validity by an expert panel, followed by an independent assessment of indicators by an expert clinical panel across various disciplines, using an online survey.

Primary outcome measure: Analysis of ratings was performed on the four key elements of preventability; the medication-related problem must be recognisable, the adverse outcomes foreseeable and the causes and outcomes identifiable and controllable.

Results: A total of 48 potential indicators across all major disease groupings were developed based on level III evidence or greater, that were independently assessed by 78 expert clinicians (22.1\% response rate). The expert panel considered 29 of these $(60.4 \%)$ sufficiently valid. Of these, $21(72.4 \%)$ were based on level I evidence.

Conclusions: This study provides a set of face and content validated indicators of medication-related potentially preventable hospitalisations, linking suboptimal processes of care and medication use with subsequent hospitalisation. Further analysis is required to establish operational validity in a population-based sample, using an administrative health database. Implementation of these indicators within routine monitoring of healthcare systems will highlight those conditions where hospitalisations could potentially be avoided through improved medication management.

\section{Strengths and limitations of this study}

- The clinical indicators developed were based on high-level evidence together with expert clinical panel assessment.

- Since the clinical indicators were developed using Australian-specific resources they may need to be adapted for use in other settings.

- This study provides a set of face and content validated indicators of potentially preventable hospitalisations, linking to suboptimal processes of care and medication use with subsequent hospitalisation.

\section{INTRODUCTION}

Clinical indicators of potentially preventable hospitalisations are used as a measure of health system performance and quality of healthcare provided to patients. ${ }^{1}{ }^{2}$ Potentially preventable hospitalisations are defined as those hospitalisations that could be prevented with the provision of timely and effective primary care. ${ }^{3}$ Medication-related hospitalisations are relatively common. A literature review found that $2-3 \%$ of all hospital admissions in the Australian healthcare setting were medication related, with half considered to be potentially preventable. ${ }^{4}$ A systematic review of studies from around the world found that a median of $3.7 \%$ of all hospital admissions were preventable medication-related admissions. ${ }^{5}$ The identification and subsequent reduction of the most common medication-related potentially preventable hospitalisations will improve morbidity and quality of life for patients, safety of the healthcare system and reduce healthcare expenditure.

Clinical indicators of medication-related potentially preventable hospitalisations have been developed which link suboptimal 
processes of care with medicine use to assess adverse outcomes including hospitalisation. ${ }^{26-8}$ The overall incidence of preventable medication-related hospitalisations when measured using these clinical indicator sets has been reported to range between $3 \%$ and $20 \%$, depending on the country of the study population and the clinical indicator set used. $^{9-11}$ Using the previously developed clinical indicators, the prevalence of potentially preventable medication-related hospitalisations in the Australian healthcare setting between 1 January 2004 and 31 December 2008 was examined. During the 5 -year study period there were $44416(20.5 \%)$ potentially preventable medication-related hospitalisations, equating to 9000 preventable admissions each year. ${ }^{11}$ However, in undertaking the study, it became apparent that many of the internationally developed indicators were not relevant or applicable to the Australian healthcare setting. A cross-country comparison between the USA and the UK indicators found that of the 46 indicators assessed, $58 \%$ were relevant to the USA but not the UK, and only $41 \%$ were deemed to be relevant in the healthcare setting of both countries. ${ }^{8}$ Given the significant differences between the USA and the UK healthcare systems to that of Australia, there may be additional indicators, specifically relevant to the Australian healthcare system, that should be examined. Further, the international indicators were developed over 10 years ago and there are likely to be a number of indicators based on new medicines introduced since then.

Prior studies which developed clinical indicators for potentially preventable medication-related hospitalisations used the Delphi technique, ${ }^{2} 681213$ which measures consensus among experts using a series of structured surveys. ${ }^{1415}$ Recent studies have highlighted the need for clinical indicators to be evidence based, rather than based on expert consensus only. ${ }^{11} 1316$ Increasingly, the RAND appropriateness method is used in indicator development, ${ }^{17}{ }^{18}$ which develops indicators by combining evidence-based recommendations from clinical guidelines with expert clinical opinion. In addition, recent studies have highlighted the need for clinical indicators to be country specific to reflect current practice within individual healthcare systems. ${ }^{11} 1316$ To date, no evidence-based indicators of medication-related potentially preventable hospitalisations have been developed specific for the Australian setting. The aim of this study was to develop and validate Australian evidence-based medication-related indicators of potentially preventable hospitalisations.

\section{METHODS}

A modified RAND appropriateness method was used for the development of medication-related indicators of potentially preventable hospitalisations, which has characteristics of both the Delphi and Nominal Group Techniques, providing a systematic method to combine evidence with expert opinion. ${ }^{19}$ It consists of a literature review, assessment of the strength of the supporting evidence base, an initial face and content validity assessment by an expert panel, followed by an independent assessment of indicators by an expert clinical panel across various disciplines, using an online survey.

\section{Identification of existing indicators and development of new indicators}

A number of methods were used to systematically identify and develop clinical indicators for medicationrelated potentially preventable hospitalisations, specific for the Australian healthcare setting. A literature review was conducted to identify all published studies of indicators for preventable medication-related hospitalisations that could be adapted using specific inclusion criteria. Identification and development of additional clinical indicators was based on chronic diseases included in Australia's National Health Priority Areas. ${ }^{20}$ In addition, indicators were developed for gastrointestinal disorders, which are associated with high prevalence and morbidity in Australia. ${ }^{21}$ Australian treatment and clinical guidelines for these chronic conditions were then examined to identify potential mediation-related issues relevant for the development of clinical indicators for preventable medication-related hospitalisations.

\section{Literature review to identify existing clinical indicators of} potentially preventable medication-related hospitalisations A literature review of all published studies on clinical indicators for preventable medication-related hospitalisations was conducted from January 2001 to December 2012, inclusive. The primary search terms used were 'indicators', 'prevent\$ OR avoid\$', 'medication OR drug-related', 'hospitalisation OR morbidity' and 'adverse drug event'. MEDLINE (via Ovid) and EMBASE were searched, with results limited to articles published in English and conducted in adults. Studies which developed indicators not associated with the outcome of hospitalisation were excluded. Reference lists of relevant identified studies were further searched to identify additional papers. The following information was extracted from each suitable study: the hospitalisation outcome, the process of care leading to the outcome and references (ie, studies which developed the indicator). Clinical indicators were grouped according to broader chronic disease groupings and similar clinical indicators obtained from different studies were recorded as one clinical indicator.

Predefined inclusion criteria were used to determine the applicability and relevance of previously published clinical indicators to the Australian healthcare setting. Indicators that did not meet one or more of these criteria were excluded from the study.

The inclusion criteria were the following:

1. Strength of supporting evidence must be Grade B or level III or higher, based on the National Health and Medical Research Council (NHMRC) evidence matrix. ${ }^{22}$ 
2. The medicine must be available in Australia and subsidised under the Schedule of Pharmaceutical Benefits (PBS or RPBS). ${ }^{23}$

3. The process of care must concur with Australian treatment guidelines.

4. The process of care can be identified in Australian electronic health records.

Concordance of the indictors with current Australian treatment and clinical guidelines were identified from the Australian Therapeutic Guidelines, ${ }^{24}$ Australian Medicines Handbook ${ }^{25}$ and clinical guidelines including cardiovascular disease, ${ }^{26-30}$ respiratory conditions, ${ }^{31}{ }^{32}$ diabetes, ${ }^{33}{ }^{34}$ musculoskeletal conditions ${ }^{35}{ }^{36}$ and mental health. ${ }^{37}$ Where the international clinical indicators differed slightly from Australian guidelines, modifications were developed if appropriate. The guidelines were also searched to determine the level of supporting evidence. The strength of the supporting evidence for each indicator was assessed and categorised into five levels based on current Australian standards, used for guideline development. ${ }^{39}$ Only those indicators with level III or greater evidence were included. The WHO International Classification of Diseases (ICD) 10-AM classification was used to identify codes for hospitalisation outcomes. ${ }^{40}$

\section{Development of new clinical indicators of potentially preventable medication-related hospitalisations}

Development of new clinical indicators was largely based on those chronic diseases included in Australia's National Health Priority Areas. ${ }^{20}$ Chronic obstructive pulmonary disease was included with asthma under the broad disease category of respiratory conditions due to its large disease burden and mortality. ${ }^{41}$ Gastrointestinal disorders which are associated with high prevalence and morbidity in Australia, were also included. ${ }^{21}$ Clinical indicators for cancer were not developed in this study. Medicine use for cancer is highly specialised and varied depending on the type of cancer, and the development of new medicines for these conditions is a fast evolving area. To develop new indicators treatment and clinical guidelines for each of the conditions were reviewed, with a focus on treatment considerations, medicine class statements and monographs, contraindications, precautions, recommended testing and follow-up. All newly developed indicators were required to meet the inclusion criteria used for previously published clinical indicators, as described above.

\section{Initial face and content validity by a convenience sample of pharmacists}

An initial face and content validity of the compiled list of indicators was undertaken with a convenience sample of eight clinical pharmacists. Based on the four elements of preventability developed by Hepler and Strand, ${ }^{42}$ they were asked the following questions: would you expect most health professionals to

1. Recognise the problem in the process of care?
2. Foresee the potential for hospitalisation associated with the process of care?

3. Know how to change the process of care to reduce the likelihood of hospitalisation?

4. Be able to change the process of care to reduce the likelihood of hospitalisation?

Responses to each of the four elements of preventability were rated on a three-point Likert scale, where ' 1 ' indicates disagreement, '2' uncertain or equivocal and ' 3 ' agreement, together with comments to allow for feedback or suggestions regarding specific elements or readability. For each indicator, a majority agreement $(5 / 8$ or $62.5 \%)$ by the convenience sample across all four elements of preventability was required for inclusion in our final list for validation by an expert panel.

\section{Expert panel assembly, survey and analysis}

The final list of indicators for validation were grouped into subject categories (cardiovascular disease, diabetes, renal, mental health, respiratory, gastrointestinal and osteoporosis/fracture indicators) and sent to clinical experts for review. Experts were identified as clinical leaders in their field, that included both medical physicians (general practitioners and specialists) and pharmacists (including certified geriatric pharmacists and clinical pharmacists), across Australia from a range of healthcare settings. A total of 352 clinical experts were identified and contacted to be part of the expert clinical panel for validation of the indicators, between December 2012 and March 2013. They were invited to score the indicators using an online survey (SurveyMonkey http:// www.surveymonkey.com) on the four elements of preventability, as described above. Participants were not able to respond to the survey more than once. A brief summary of each indicator was provided; the level of evidence for each indicator together with the reference(s) supporting the level of evidence. A priori criteria of consensus for validation for each of the indicators were defined; an average score of $70 \%$ or greater agreement by the expert panellists, across all four elements of preventability for each indicator, were deemed to meet requirements for validation of an indicator. As described above, responses to each of the four elements of preventability were rated on a three-point Likert scale, where ' 1 ' indicates disagreement, '2' uncertain or equivocal and ' 3 ' agreement, together with comments to allow for feedback on each of the individual indicators.

\section{RESULTS}

A total of 48 potential indicators across major disease groupings based on level III evidence or greater were developed (table 1), all of which had majority agreement in the initial face and content validity by a convenience sample of eight clinical pharmacists. Of these, 13 were from previously developed medication-related indicators of potentially preventable hospitalisations, 15 were modified to be applicable to the Australian healthcare 


\begin{tabular}{|c|c|c|c|c|c|c|}
\hline \multirow[b]{2}{*}{ Number } & \multirow[b]{2}{*}{$\begin{array}{l}\text { Hospitalisation } \\
\text { outcome }\end{array}$} & \multirow[b]{2}{*}{ Process of care (preceding hospitalisation) } & \multirow[b]{2}{*}{ Level of evidence } & \multicolumn{3}{|c|}{ Source of indicator } \\
\hline & & & & $\begin{array}{l}\text { Previously } \\
\text { published; not } \\
\text { modified }\end{array}$ & $\begin{array}{l}\text { Previously published; } \\
\text { modified for this study }\end{array}$ & $\begin{array}{l}\text { Newly } \\
\text { developed }\end{array}$ \\
\hline 15 & Serotonin toxicity & $\begin{array}{l}\text { Use of duloxetine, fentanyl, tramadol, SSRIs, TCAs or } \\
\text { venlafaxine concurrently with MAOI or moclobemide, or } \\
\text { within } 14 \text { days of stopping MAOI }\end{array}$ & Level III ${ }^{54}$ & & & 25 \\
\hline 16 & Serotonin toxicity & $\begin{array}{l}\text { Concurrent treatment with strong CYP1A2 inhibitors (eg, } \\
\text { duloxetine) with fluvoxamine }\end{array}$ & Level III ${ }^{54}$ & & & 25 \\
\hline \multicolumn{7}{|c|}{ Respiratory indicators } \\
\hline 17 & Asthma or COPD & $\begin{array}{l}\text { 1. History of asthma or COPD } \\
\text { 2. Use of a } \beta \text {-blocker eye drops for glaucoma }\end{array}$ & Level I ${ }^{55}$ & 813 & & \\
\hline 18 & Asthma & $\begin{array}{l}\text { 1. History of asthma } \\
\text { 2. Use of SABA more than } 3 \text { times/week or use of LABA } \\
\text { 3. No use of inhaled corticosteroids }\end{array}$ & Level I ${ }^{32}$ & & $\begin{array}{l}\text { Asthma only, Australian } \\
\text { guideline specific }^{7-9}\end{array}$ & \\
\hline 19 & COPD & $\begin{array}{l}\text { 1. Moderate to severe COPD with frequent exacerbation } \\
\text { 2. Use of long-acting } \beta \text {-agonist or anticholinergic } \\
\text { 3. No use of inhaled corticosteroids }\end{array}$ & Level I ${ }^{31}$ & & $\begin{array}{l}\text { COPD only, Australian } \\
\text { guideline specific }^{7-9}\end{array}$ & \\
\hline 20 & Asthma or COPD & $\begin{array}{l}\text { 1. History of asthma or COPD } \\
\text { 2. No contraindication to influenza vaccine } \\
\text { 3. No influenza vaccination in the previous year }\end{array}$ & Level ${ }^{31} 32$ & & & 3132 \\
\hline 21 & $\begin{array}{l}\text { Influenza-related } \\
\text { pneumonia }\end{array}$ & $\begin{array}{l}\text { 1. Patient aged } \geq 65 \\
\text { 2. No contraindication to influenza vaccine } \\
\text { 3. No influenza vaccine in the previous year }\end{array}$ & Level I 5657 & 2 & & \\
\hline 22 & $\begin{array}{l}\text { Pneumococcal } \\
\text { pneumonia or sepsis }\end{array}$ & $\begin{array}{l}\text { 1. Patient aged } \geq 65 \\
\text { 2. No contraindication to pneumococcal vaccine } \\
\text { 3. No pneumococcal vaccine in the previous } 6 \text { years }\end{array}$ & Level III ${ }^{57} 58$ & 2 & & \\
\hline \multicolumn{7}{|c|}{ 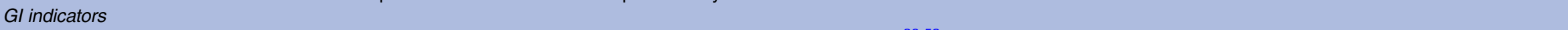 } \\
\hline 23 & $\begin{array}{l}\text { Gl bleed, perforation or } \\
\text { ulcer or gastritis }\end{array}$ & $\begin{array}{l}\text { 1. History of GI ulcer or bleeding } \\
\text { 2. NSAID use for at least } 1 \text { month } \\
\text { 3. No use of gastroprotective agent (eg, PPI) }\end{array}$ & Level II ${ }^{36} 59$ & & $\begin{array}{l}\text { Added gastroprotective } \\
\text { agent }^{6} 713\end{array}$ & \\
\hline 24 & $\begin{array}{l}\text { Chronic constipation or } \\
\text { impaction }\end{array}$ & $\begin{array}{l}\text { 1. Use of two or more agents with low-to-moderate } \\
\text { anticholinergic activity; OR use of a highly anticholinergic } \\
\text { agent }\end{array}$ & Level $1^{60}$ & 2 & & \\
\hline 25 & $\begin{array}{l}\text { Chronic constipation or } \\
\text { impaction }\end{array}$ & $\begin{array}{l}\text { 1. Regular use of a strong opioid analgesic (fentanyl, } \\
\text { oxycodone, morphine) } \\
\text { 2. No concurrent use of a laxative }\end{array}$ & Level $I^{61}$ & 8 & & \\
\hline 26 & GI ulcer & $\begin{array}{l}\text { 1. Patient with dyspepsia } \\
\text { 2. PPI not prescribed }\end{array}$ & Level $1^{62}$ & & & 25 \\
\hline 27 & GI ulcer & $\begin{array}{l}\text { 1. Patient with a positive test for Helicobacter pylori } \\
\text { 2. Not prescribed } \mathrm{H} \text { pylori eradication therapy }\end{array}$ & Level I ${ }^{63}$ & & & 25 \\
\hline 28 & GI ulcer or bleed & $\begin{array}{l}\text { 1. Patient with osteoarthritis } \\
\text { 2. Dispensed long-term NSAIDs (including COX-2) therapy }\end{array}$ & Level $1^{64}$ & & & 36 \\
\hline 29 & $\begin{array}{l}\text { Oesophagitis, } \\
\text { oesophageal ulceration } \\
\text { or stricture }\end{array}$ & $\begin{array}{l}\text { 1. History of oesophageal disorders (active oesophagitis, } \\
\text { oesophageal ulceration, stricture or achalasia) } \\
\text { 2. Use of alendronate }\end{array}$ & Level $1^{65}$ & & & 25 \\
\hline
\end{tabular}


Hospitalisation

\section{Number outcome}

Process of care (preceding hospitalisation)

Osteoporosis/fracture indicators

30a Osteoporosis or fracture

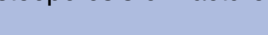

Use of systemic corticosteroids for at least 3 months

2. No osteoporosis prophylaxis (women: no use of HRT,

bisphosphonate, teriparatide, selective oestrogen receptor modulators or strontium; men: no use of bisphosphonate or teriparatide)

30b Osteoporosis or fracture Fracture

This indicator is the same as above, but for male patients

1. Female patient

2. History of osteoporosis or fracture

3. No use of HRT, bisphosphonate, teriparatide, selective

oestrogen receptor modulators or strontium

1. Male patient

. History of osteoporosis or fracture

3. No use of bisphosphonate or teriparatide

1. Patient aged $\geq 65$ years

2. History of osteoporosis

3. Patient not receiving adequate levels of calcium and vitamin D

1. Patient on high dose inhaled corticosteroid $(\geq 400 \mu \mathrm{g}$ fluticasone daily or equivalent) for more than 1 year

2. Bone mineral density not measured in the previous 24 months

1. Patient aged $\geq 65$ years

2. Use of a falls-risk medicine (eg, long-acting hypnotic or anxiolytic, tricyclic antidepressant)

1. Concurrent use of calcitriol with digoxin

2. Calcium concentration not monitored in the previous 3 months

1. Use of calcitriol

2. Plasma calcium concentration not monitored in the previous 3 months

Renal indicators

$38 \quad$ Renal failure or nephropathy

1. History of diabetes

2. Microalbuminuria and plasma creatinine not monitored in the previous 12 months

3. Patient not on ACEI or ARB

1. NSAID use for $>3$ months

2. Serum creatinine not monitored in the previous 12 month

1. Use of lithium

2. Serum creatinine not monitored in previous 6 months

1. History of BPH

2. Use of an anticholinergic agent

$41 \quad$ Urinary retention
Source of indicator

Previously

published; not

modified

Previously published;

Newly

Level of evidence

modified for this study

developed

Level I ${ }^{66}$

Removed dose ${ }^{813}$

Level I ${ }^{66}$

Removed dose $e^{813}$

Changed from history

of fall ${ }^{6}$

Level II ${ }^{35}$

Changed from history of fall ${ }^{2}$

Level III ${ }^{35}$

Level II ${ }^{35}$

Level I ${ }^{67}$

Included all falls-risk medicines $^{6-8}$

Level III ${ }^{68}$

Level II-monitoring

Level I-ACE/ARB

use $^{70}$

Level II ${ }^{36}$

Changed monitoring from 3

Level III ${ }^{38}$

to 12 months $^{68}$

Level III ${ }^{25}$ 


\section{Table 1 Continued}

\begin{tabular}{|c|c|c|c|c|c|c|}
\hline Number & $\begin{array}{l}\text { Hospitalisation } \\
\text { outcome }\end{array}$ & Process of care (preceding hospitalisation) & Level of evidence & $\begin{array}{l}\text { published; not } \\
\text { modified }\end{array}$ & $\begin{array}{l}\text { Previously published; } \\
\text { modified for this study }\end{array}$ & $\begin{array}{l}\text { Newly } \\
\text { developed }\end{array}$ \\
\hline 42 & Urinary retention & $\begin{array}{l}\text { 1. Use of two or more agents with anticholinergic activity OR } \\
\text { use of a highly anticholinergic agent }\end{array}$ & Level IIII & & Combined to one indicator ${ }^{2}$ & \\
\hline \multicolumn{7}{|c|}{ Diabetes indicators } \\
\hline 43 & $\begin{array}{l}\text { Hyperglycaemia/ } \\
\text { hypoglycaemia }\end{array}$ & $\begin{array}{l}\text { 1. Use of an oral hypoglycaemic agent } \\
\text { 2. HbA1c level not monitored in the previous } 6 \text { months }\end{array}$ & Level I ${ }^{34}$ & & $\begin{array}{l}\text { Added hypoglycaemia } \\
\text { as outcome }{ }^{26}\end{array}$ & \\
\hline 44 & Hypoglycaemia & $\begin{array}{l}\text { 1. Use of a long-acting oral hypoglycaemic agent } \\
\text { (glibenclamide or glimepiride) } \\
\text { 2. HbA1c level not monitored in the previous } 6 \text { months }\end{array}$ & Level I ${ }^{34}$ & & Added $\mathrm{HbA} 1 \mathrm{c}$ monitoring ${ }^{2}$ & \\
\hline 45 & $\begin{array}{l}\text { Hyperglycaemia or } \\
\text { hypoglycaemia }\end{array}$ & $\begin{array}{l}\text { 1. Use of insulin } \\
\text { 2. HbA1c level not monitored in the previous } 6 \text { months }\end{array}$ & Level I ${ }^{34}$ & & & 34 \\
\hline 46 & $\begin{array}{l}\text { Hyperglycaemia or } \\
\text { hypoglycaemia }\end{array}$ & $\begin{array}{l}\text { 1. Use of insulin or oral hypoglycaemic medicines } \\
\text { 2. Use of medicines that may increase or decrease blood } \\
\text { glucose concentration } \\
\text { 3. HbA1c level not monitored in the previous } 6 \text { months }\end{array}$ & Level I3 & & & 33 \\
\hline 47 & Hypoglycaemia & $\begin{array}{l}\text { 1. Use of glibenclamide or glimepiride } \\
\text { 2. Renal function not monitored in the previous year }\end{array}$ & Level II ${ }^{33}$ & & & 33 \\
\hline 48 & Cardiovascular disease & $\begin{array}{l}\text { 1. History of diabetes } \\
\text { 2. Not on lipid lowering drug }\end{array}$ & Level $I^{71}$ & & & 71 \\
\hline
\end{tabular}

ARB, angiotensin receptor blocker; $\mathrm{BPH}$, benign prostatic hyperplasia; $\mathrm{CHF}$, congestive heart failure; COPD, chronic obstructive pulmonary disease; GI, gastrointestinal; $\mathrm{HbA1C}$, glycated haemoglobin; HRT, hormone replacement therapy; IHD, ischemic heart disease; LABA, long-acting $\beta$ agonist; MAOI, monoamine oxidase inhibitor; MI, myocardial infarction; NSAID, non-steroidal anti-inflammatory drug; PPI, proton pump inhibitor; SSRI, selective serotonin reuptake inhibitor; TCA, transluminal coronary angioplasty; VTE, venous thromboembolism. 
setting and 21 were newly developed. These were then sent to the expert clinical panel for full validation and were independently assessed by 78 expert clinicians (22.2\% response rate). Of the respondents, $32 \%$ were medical physicians and $68 \%$ were pharmacists.

The expert panel considered 29 of these $(60.4 \%)$ to be sufficiently valid based on the a priori developed criteria (table 2). The majority of these $(72.4 \%, \mathrm{n}=21)$ were based on level I evidence. A total of 11 cardiovascular indicators were developed, of which $5(45.5 \%)$ were validated by the expert clinical panel; four of the five were based on level I evidence. Of the five mental health indicators developed, only one had level I evidence and none were validated by the expert panel. Six respiratory indicators were developed and five of these were validated, $80 \%$ of these were based on level I evidence. A total of seven gastrointestinal indicators, six of which were based on level I evidence were developed and five $(71.4 \%)$ were validated. Of eight osteoporosis/ fracture indicators, half of which were based on level I evidence and five $(62.5 \%)$ were validated. Only two of the five developed renal indicators were validated, with the level of evidence being level II or less for these. Finally, six diabetes indicators were developed, four of which were based on level I evidence and all were validated by the clinical panel.

\section{DISCUSSION}

This study provides a set of face and content validated indicators of medication-related potentially preventable hospitalisations, specific for the Australian healthcare setting linking suboptimal processes of care and medication use with subsequent hospitalisation. Of a potential 48 developed indicators, 29 achieved consensus validation by the expert clinical panel and over $70 \%$ of these were based on level I evidence. An important feature of these developed indicators is that they are evidence based, systematically combining evidencebased recommendations from clinical guidelines with expert clinical opinion. In addition, these indicators focus on those chronic conditions which are included in Australia's National Health Priority Areas ${ }^{20}$ or those that are associated with high disease burden in Australia. ${ }^{21} 41$

For each of the six disease clusters for which indicators were developed, the proportion validated by our expert panel ranged from only $20 \%(1 / 5)$ for the mental health indicators to $100 \%$ for the diabetes indicators $(6 / 6)$. Interestingly, the level of evidence available for the metal health indicators around medicine use and processes of care was minimal (four of the five indicators had only level III evidence), by comparison to the diabetes indicators where the majority of evidence was level I.

The health conditions for which these indicators were developed significantly contribute to the burden of illness, social and financial costs in Australia, and prevention of hospitalisations associated with these conditions will provide significant gains in the health of Australia's population. ${ }^{20}$ Furthermore, given the high prevalence of medication-related hospitalisations in Australia, identification of areas where medication management could be improved, particularly at the primary care level, may also lead to fewer hospitalisations. An estimated 90000 hospital admissions annually are considered to be potentially preventable mediation-related admissions in those aged 65 years and older. ${ }^{11}$ Based on the average cost of hospitalisation in Australia in 2010 2011 to be $\$ A 5400,{ }^{43}$ these unnecessary hospitalisations cost Australia's healthcare system \$A480 million annually.

Analysis of the developed indicators in a populationbased sample is required to establish operational validity, and this will be the focus of the next phase of this research. With the advent of computerised administrative health databases, these indicators have been developed with the potential to be analysed in such databases at the population level. Importantly, the characteristics of those patients' most vulnerable to mediation-related hospitalisations will also facilitate the identification of risk-factors associated with suboptimal medication management. Implementation of these indicators within routine monitoring of the Australian healthcare system will serve to highlight those conditions where hospitalisations could potentially be avoided through improved medication management, identify areas of current practice that may be suboptimal or evidence-practice gaps and facilitate the development of specific interventions to improve healthcare and subsequent patient outcomes.

The standard RAND appropriateness method employs two rounds; in the first round experts rate indicators independently and in the second round, experts meet face to face to discuss the indicators and rate the indicators again, based on the face-to-face discussion. ${ }^{17}$ Our study used a modified RAND appropriateness method, with one round of independent expert panel review, and subsequent inclusion of indicators which met a priori defined criteria but no face-to-face meeting of experts. This is a potential limitation of our study, because the face-to-face meeting provides an opportunity to discuss indicators with low levels of agreement between experts, and can identify whether this is due to true clinical disagreement or simply an issue with the wording of the indicator. ${ }^{44}$ It may be that for some indicators true consensus was not achieved if those who disagreed were strongly opposed to the indicator, and this type of issue may have been identified at a face-to-face meeting. Despite these limitations, the online survey technique used in our study eliminates any potential bias from dominant individuals who may be associated with face-to-face panel settings. ${ }^{44}$ This allows for expert clinical panel members to express their opinions in an anonymous manner but also gives them time to consider each of the four elements of preventability together with 
Table 2 Validation of Australian medication-related potentially preventable hospitalisation clinical indicator set by expert panel

\begin{tabular}{|c|c|c|c|c|c|c|c|c|}
\hline \multirow[b]{2}{*}{ Number } & \multirow[b]{2}{*}{$\begin{array}{l}\text { Hospitalisation } \\
\text { outcome }\end{array}$} & \multirow[b]{2}{*}{$\begin{array}{l}\text { Process of care } \\
\text { (preceding hospitalisation) }\end{array}$} & \multirow[b]{2}{*}{ Accepted } & \multirow[b]{2}{*}{$\begin{array}{l}\text { Overall } \\
\text { score } \\
(\%)\end{array}$} & \multicolumn{4}{|c|}{ Would you expect most health professionals to* } \\
\hline & & & & & $\begin{array}{l}\text { Recognise the } \\
\text { problem in the } \\
\text { process of } \\
\text { care? (\%) }\end{array}$ & $\begin{array}{l}\text { Foresee the potential } \\
\text { for hospitalisation } \\
\text { associated with the } \\
\text { process of care? (\%) }\end{array}$ & $\begin{array}{l}\text { Know how to change } \\
\text { the process of care to } \\
\text { reduce the likelihood } \\
\text { of hospitalisation? (\%) }\end{array}$ & $\begin{array}{l}\text { Be able to change the } \\
\text { process of care to } \\
\text { reduce the likelihood } \\
\text { of hospitalisation? (\%) }\end{array}$ \\
\hline \multicolumn{9}{|c|}{ Cardiovascular indicators } \\
\hline 1 & $\begin{array}{l}\text { Acute coronary } \\
\text { syndrome }\end{array}$ & $\begin{array}{l}\text { 1. History of MI (in } 2 \text { years prior to } \\
\text { admission) } \\
\text { 2. Not on aspirin, } \beta \text {-blocker, ACEI } \\
\text { or ARB and statin (in } 3 \text { months } \\
\text { prior to admission) }\end{array}$ & $\mathbf{Y}$ & 71.5 & 74 & 79 & 74 & 63 \\
\hline 2 & $\begin{array}{l}\text { Acute coronary } \\
\text { syndrome }\end{array}$ & $\begin{array}{l}\text { 1. Patient has coronary artery stent } \\
\text { (in } 1 \text { years prior to admission) } \\
\text { 2. No use of aspirin or clopidogrel } \\
\text { (in } 12 \text { months prior to } \\
\text { admission) }\end{array}$ & $\mathbf{Y}$ & 75 & 78 & 72 & 72 & 78 \\
\hline 3 & $\mathrm{CHF}$ & $\begin{array}{l}\text { 1. History of CHF (in } 2 \text { years prior } \\
\text { to admission) } \\
\text { 2. Not on an ACEI or ARB (in } \\
3 \text { months prior to admission) }\end{array}$ & $Y$ & 72.5 & 80 & 70 & 70 & 70 \\
\hline 4 & $\mathrm{CHF}$ & $\begin{array}{l}\text { 1. History of CHF (in } 2 \text { years prior } \\
\text { to admission) } \\
\text { 2. Not on a heart failure indicated } \\
\beta \text {-blocker (in } 3 \text { months prior to } \\
\text { admission) }\end{array}$ & $\mathrm{N}$ & 63 & 68 & 63 & 63 & 58 \\
\hline 5 & $\mathrm{CHF}$ & $\begin{array}{l}\text { 1. History of CHF } \\
\text { 2. Use of rosiglitazone or } \\
\text { pioglitazone (in } 6 \text { months prior } \\
\text { to admission) }\end{array}$ & $N$ & 38 & 35 & 29 & 47 & 41 \\
\hline 6 & $\mathrm{CHF}$ & $\begin{array}{l}\text { 1. History of CHF } \\
\text { 2. Use of NSAID (in } 3 \text { months prior } \\
\text { to admission) }\end{array}$ & $N$ & 54.5 & 56 & 56 & 50 & 56 \\
\hline 7 & $\begin{array}{l}\text { CHF or cardiac } \\
\text { ischaemic event }\end{array}$ & $\begin{array}{l}\text { 1. History of IHD (in } 2 \text { years prior } \\
\text { to admission) } \\
\text { 2. Use of rosiglitazone (in } \\
6 \text { months prior to admission) }\end{array}$ & $\mathrm{N}$ & 36 & 33 & 28 & 44 & 39 \\
\hline 8 & $\begin{array}{l}\mathrm{CHF} \text { and/or heart } \\
\text { block }\end{array}$ & $\begin{array}{l}\text { 1. History of } \mathrm{CHF} \text { with heart block } \\
\text { or advanced bradycardia (in } \\
2 \text { years prior to admission) } \\
\text { 2. Use of digoxin (in } 6 \text { months } \\
\text { prior to admission) }\end{array}$ & $\mathbf{Y}$ & 75 & 80 & 85 & 75 & 60 \\
\hline 9 & $\mathrm{CHF}$ or $\mathrm{Ml}$ & $\begin{array}{l}\text { 1. Concurrent use of insulin and } \\
\text { rosiglitazone }\end{array}$ & $\mathrm{N}$ & 48.5 & 53 & 41 & 53 & 47 \\
\hline
\end{tabular}




\begin{tabular}{|c|c|c|c|c|c|c|c|c|}
\hline \multirow[b]{2}{*}{ Number } & \multirow[b]{2}{*}{$\begin{array}{l}\text { Hospitalisation } \\
\text { outcome }\end{array}$} & \multirow[b]{2}{*}{$\begin{array}{l}\text { Process of care } \\
\text { (preceding hospitalisation) }\end{array}$} & \multirow[b]{2}{*}{ Accepted } & \multirow[b]{2}{*}{$\begin{array}{l}\text { Overall } \\
\text { score } \\
(\%)\end{array}$} & \multicolumn{4}{|c|}{ Would you expect most health professionals to* } \\
\hline & & & & & $\begin{array}{l}\text { Recognise the } \\
\text { problem in the } \\
\text { process of } \\
\text { care? }(\%)\end{array}$ & $\begin{array}{l}\text { Foresee the potential } \\
\text { for hospitalisation } \\
\text { associated with the } \\
\text { process of care? (\%) }\end{array}$ & $\begin{array}{l}\text { Know how to change } \\
\text { the process of care to } \\
\text { reduce the likelihood } \\
\text { of hospitalisation? (\%) }\end{array}$ & $\begin{array}{l}\text { Be able to change the } \\
\text { process of care to } \\
\text { reduce the likelihood } \\
\text { of hospitalisation? (\%) }\end{array}$ \\
\hline 10 & Ischaemic stroke & $\begin{array}{l}\text { 1. History of chronic AF or } \\
\text { ischaemic stroke (in } 2 \text { years } \\
\text { prior to admission) } \\
\text { 2. No use of warfarin or aspirin (in } \\
3 \text { months prior to admission) }\end{array}$ & $\mathbf{Y}$ & 94.8 & 100 & 100 & 95 & 84 \\
\hline 11 & VTE or stroke & $\begin{array}{l}\text { 1. History of coronary artery } \\
\text { disease or VTE } \\
\text { 2. Use of raloxifene }\end{array}$ & $\mathrm{N}$ & 54.8 & 56 & 50 & 63 & 50 \\
\hline \multicolumn{9}{|c|}{ Mental health indicators } \\
\hline 12 & Bipolar disorder & $\begin{array}{l}\text { 1. History of bipolar disorder } \\
\text { 2. Use of lithium } \\
\text { 3. 3) Drug level not monitored in } \\
\text { the previous } 3 \text { months }\end{array}$ & $\mathrm{N}$ & 69 & 69 & 63 & 75 & 69 \\
\hline 13 & Acute confusion & $\begin{array}{l}\text { 1. Patient aged } \geq 65 \text { years } \\
\text { 2. Use of } 2 \text { or more agents with } \\
\text { anticholinergic activity OR use } \\
\text { of an agent with high } \\
\text { anticholinergic activity }\end{array}$ & $\mathrm{N}$ & 53.5 & 44 & 44 & 63 & 63 \\
\hline 14 & Acute confusion & $\begin{array}{l}\text { 1. Patient aged } \geq 65 \text { years } \\
\text { 2. Use of multiple psychotropic } \\
\text { medications (eg, } \\
\text { benzodiazepines, tricyclic } \\
\text { antidepressants) }\end{array}$ & $\mathrm{N}$ & 42.6 & 69 & 50 & 56 & 38 \\
\hline 15 & Serotonin toxicity & $\begin{array}{l}\text { 1. Use of duloxetine, fentanyl, } \\
\text { tramadol, SSRIs, TCAs, or } \\
\text { venlafaxine concurrently with } \\
\text { MAOI or moclobemide, or within } \\
14 \text { days of stopping MAOI }\end{array}$ & $\mathrm{N}$ & 53 & 50 & 50 & 56 & 56 \\
\hline 16 & Serotonin toxicity & $\begin{array}{l}\text { 1. Concurrent treatment with strong } \\
\text { CYP1A2 inhibitors (eg, } \\
\text { duloxetine) with fluvoxamine }\end{array}$ & $\mathrm{N}$ & 59.5 & 63 & 56 & 63 & 56 \\
\hline \multicolumn{9}{|c|}{ Respiratory indicators } \\
\hline 17 & Asthma or COPD & $\begin{array}{l}\text { 1. History of asthma or COPD } \\
\text { 2. Use of a } \beta \text {-blocker eye drops for } \\
\text { glaucoma }\end{array}$ & $\mathrm{N}$ & 51.2 & 50 & 45 & 50 & 60 \\
\hline 18 & Asthma & $\begin{array}{l}\text { 1. History of asthma } \\
\text { 2. Use of SABA more than } 3 \\
\text { times/week or use of LABA } \\
\text { 3. No use of inhaled } \\
\text { corticosteroids }\end{array}$ & $\mathbf{Y}$ & 92.5 & 95 & 85 & 100 & 90 \\
\hline
\end{tabular}


Would you expect most health professionals to*

\begin{tabular}{|c|c|c|c|c|c|c|c|c|}
\hline \multirow[b]{2}{*}{ Number } & \multirow[b]{2}{*}{$\begin{array}{l}\text { Hospitalisation } \\
\text { outcome }\end{array}$} & \multirow[b]{2}{*}{$\begin{array}{l}\text { Process of care } \\
\text { (preceding hospitalisation) }\end{array}$} & \multirow[b]{2}{*}{ Accepted } & \multirow[b]{2}{*}{$\begin{array}{l}\text { Overall } \\
\text { score } \\
(\%)\end{array}$} & \multicolumn{4}{|c|}{ Would you expect most health professionals to* } \\
\hline & & & & & $\begin{array}{l}\text { Recognise the } \\
\text { problem in the } \\
\text { process of } \\
\text { care? (\%) }\end{array}$ & $\begin{array}{l}\text { Foresee the potential } \\
\text { for hospitalisation } \\
\text { associated with the } \\
\text { process of care? (\%) }\end{array}$ & $\begin{array}{l}\text { Know how to change } \\
\text { the process of care to } \\
\text { reduce the likelihood } \\
\text { of hospitalisation? (\%) }\end{array}$ & $\begin{array}{l}\text { Be able to change the } \\
\text { process of care to } \\
\text { reduce the likelihood } \\
\text { of hospitalisation? (\%) }\end{array}$ \\
\hline 19 & COPD & $\begin{array}{l}\text { 1. Moderate-to-severe COPD with } \\
\text { frequent exacerbation } \\
\text { 2. Use of long-acting } \beta \text {-agonist or } \\
\text { anticholinergic } \\
\text { 3. No use of inhaled } \\
\text { corticosteroids }\end{array}$ & $\mathbf{Y}$ & 90 & 90 & 75 & 100 & 95 \\
\hline 20 & Asthma or COPD & $\begin{array}{l}\text { 1. History of asthma or COPD } \\
\text { 2. No contraindication to influenza } \\
\text { vaccine } \\
\text { 3. No influenza vaccination in the } \\
\text { previous year }\end{array}$ & $\mathbf{Y}$ & 82.5 & 80 & 75 & 90 & 85 \\
\hline 21 & $\begin{array}{l}\text { Influenza-related } \\
\text { pneumonia }\end{array}$ & $\begin{array}{l}\text { 1. Patient aged } \geq 65 \text { years } \\
\text { 2. No contraindication to influenza } \\
\text { vaccine } \\
\text { 3. No influenza vaccine in the } \\
\text { previous year }\end{array}$ & $\mathbf{Y}$ & 87.5 & 85 & 75 & 95 & 95 \\
\hline 22 & $\begin{array}{l}\text { Pneumococcal } \\
\text { pneumonia or } \\
\text { sepsis }\end{array}$ & $\begin{array}{l}\text { 1. Patient aged } \geq 65 \text { years } \\
\text { 2. No contraindication to } \\
\text { pneumococcal vaccine } \\
\text { 3. No pneumococcal vaccine in } \\
\text { the previous } 6 \text { years }\end{array}$ & $\mathbf{Y}$ & 80 & 80 & 75 & 90 & 75 \\
\hline \multicolumn{9}{|c|}{ Gl indicators } \\
\hline 23 & $\begin{array}{l}\text { Gl bleed, } \\
\text { perforation or ulcer } \\
\text { or gastritis }\end{array}$ & $\begin{array}{l}\text { 1. History of GI ulcer or bleeding } \\
\text { 2. NSAID use for at least } 1 \text { month } \\
\text { 3. 3) No use of gastroprotective } \\
\text { agent (eg, PPI) }\end{array}$ & $\mathbf{Y}$ & 89.5 & 95 & 84 & 95 & 84 \\
\hline 24 & $\begin{array}{l}\text { Chronic } \\
\text { constipation or } \\
\text { impaction }\end{array}$ & $\begin{array}{l}\text { 1. Use of } 2 \text { or more agents with } \\
\text { low-to-moderate anticholinergic } \\
\text { activity; OR use of a highly } \\
\text { anticholinergic agent }\end{array}$ & $\mathrm{N}$ & 34.3 & 42 & 21 & 37 & 37 \\
\hline 25 & $\begin{array}{l}\text { Chronic } \\
\text { constipation or } \\
\text { impaction }\end{array}$ & $\begin{array}{l}\text { 1. Regular use of a strong opioid } \\
\text { analgesic (fentanyl, oxycodone, } \\
\text { morphine) } \\
\text { 2. No concurrent use of a laxative }\end{array}$ & $\mathbf{Y}$ & 91 & 95 & 79 & 95 & 95 \\
\hline 26 & Gl ulcer & $\begin{array}{l}\text { 1. Patient with dyspepsia } \\
\text { 2. PPI not prescribed }\end{array}$ & $\mathbf{Y}$ & 74.8 & 89 & 58 & 84 & 68 \\
\hline 27 & Gl ulcer & $\begin{array}{l}\text { 1. Patient with a positive test for } \\
\text { Helicobacter pylori } \\
\text { 2. Not prescribed } H \text { pylori } \\
\text { eradication therapy (PPI twice } \\
\text { daily, clarithromycin } 500 \mathrm{mg} \\
\text { twice daily and amoxycillin } 1 \mathrm{~g} \\
\text { twice daily for } 7 \text { days; OR PPI }\end{array}$ & $\mathbf{Y}$ & 86.8 & 89 & 74 & 95 & 89 \\
\hline
\end{tabular}


tronidazole $400 \mathrm{mg}$ twice

day for

disorders (active oesophagitis

Use of systemic corticosteroids 
Would you expect most health professionals to*

\begin{tabular}{|c|c|c|c|c|c|c|c|c|}
\hline \multirow[b]{2}{*}{ Number } & \multirow[b]{2}{*}{$\begin{array}{l}\text { Hospitalisation } \\
\text { outcome }\end{array}$} & \multirow[b]{2}{*}{$\begin{array}{l}\text { Process of care } \\
\text { (preceding hospitalisation) }\end{array}$} & \multirow[b]{2}{*}{ Accepted } & \multirow[b]{2}{*}{$\begin{array}{l}\text { Overall } \\
\text { score } \\
(\%)\end{array}$} & \multicolumn{4}{|c|}{ Would you expect most health professionals to } \\
\hline & & & & & $\begin{array}{l}\text { Recognise the } \\
\text { problem in the } \\
\text { process of } \\
\text { care? }(\%)\end{array}$ & $\begin{array}{l}\text { Foresee the potential } \\
\text { for hospitalisation } \\
\text { associated with the } \\
\text { process of care? }(\%)\end{array}$ & $\begin{array}{l}\text { Know how to change } \\
\text { the process of care to } \\
\text { reduce the likelihood } \\
\text { of hospitalisation? (\%) }\end{array}$ & $\begin{array}{l}\text { Be able to change the } \\
\text { process of care to } \\
\text { reduce the likelihood } \\
\text { of hospitalisation? (\%) }\end{array}$ \\
\hline 34 & Fracture & $\begin{array}{l}\text { 1. Patient on high dose inhaled } \\
\text { corticosteroid ( } \geq 400 \mu \mathrm{g} \\
\text { fluticasone daily or equivalent) } \\
\text { for more than } 1 \text { year } \\
\text { 2. Bone mineral density not } \\
\text { measured in the previous } \\
24 \text { months }\end{array}$ & $\mathrm{N}$ & 40.8 & 45 & 32 & 45 & 41 \\
\hline 35 & Fracture & $\begin{array}{l}\text { 1. Patient aged } \geq 65 \text { years } \\
\text { 2. Use of a falls-risk medicine (eg, } \\
\text { long-acting hypnotic or } \\
\text { anxiolytic, tricyclic } \\
\text { antidepressant) }\end{array}$ & $\mathbf{Y}$ & 71.5 & 82 & 77 & 68 & $59 \%$ \\
\hline 36 & Arrhythmia & $\begin{array}{l}\text { 1. Concurrent use of calcitriol with } \\
\text { digoxin } \\
\text { 2. Calcium concentration not } \\
\text { monitored in the previous } \\
3 \text { months }\end{array}$ & $\mathrm{N}$ & 31.5 & 18 & 18 & 45 & 45 \\
\hline 37 & Hypercalcaemia & $\begin{array}{l}\text { 1. Use of calcitriol } \\
\text { 2. Plasma calcium concentration } \\
\text { not monitored in the previous } \\
3 \text { months }\end{array}$ & $\mathrm{N}$ & 62.8 & 73 & 55 & 64 & 59 \\
\hline \multicolumn{9}{|c|}{ Renal indicators } \\
\hline 38 & $\begin{array}{l}\text { Renal failure or } \\
\text { nephropathy }\end{array}$ & $\begin{array}{l}\text { 1. History of diabetes } \\
\text { 2. Microalbuminuria and plasma } \\
\text { creatinine not monitored in the } \\
\text { previous } 12 \text { months } \\
\text { 3. Patient not on ACEI or ARB }\end{array}$ & $\mathbf{Y}$ & 79.3 & 88 & 65 & 82 & 82 \\
\hline 39 & Renal failure & $\begin{array}{l}\text { 1. NSAID use for }>3 \text { months } \\
\text { 2. Serum creatinine not monitored } \\
\text { in the previous } 12 \text { months }\end{array}$ & $\mathbf{Y}$ & 79 & 76 & 76 & 88 & 76 \\
\hline 40 & Renal failure & $\begin{array}{l}\text { 1. Use of lithium } \\
\text { 2. Serum creatinine not monitored } \\
\text { in the previous } 3 \text { months }\end{array}$ & $\mathrm{N}$ & 66.5 & 65 & 65 & 65 & 71 \\
\hline 41 & Urinary retention & $\begin{array}{l}\text { 1. History of BPH } \\
\text { 2. Use of an anticholinergic agent }\end{array}$ & $\mathrm{N}$ & 59 & 59 & 65 & 59 & 53 \\
\hline 42 & Urinary retention & $\begin{array}{l}\text { 1. Use of } 2 \text { or more agents with } \\
\text { anticholinergic activity OR use } \\
\text { of a highly anticholinergic agent }\end{array}$ & $\mathrm{N}$ & 39.5 & 35 & 41 & 41 & 41 \\
\hline \multicolumn{9}{|c|}{ Diabetes indicators } \\
\hline 43 & $\begin{array}{l}\text { Hyperglycaemia/ } \\
\text { hypoglycaemia }\end{array}$ & $\begin{array}{l}\text { 1. Use of an oral hypoglycaemic } \\
\text { agent } \\
\text { 2. HbA1c level not monitored in } \\
\text { the previous } 6 \text { months }\end{array}$ & $\mathbf{Y}$ & 85 & 95 & 77 & 95 & 73 \\
\hline
\end{tabular}




\begin{tabular}{|c|c|c|c|c|c|c|c|c|}
\hline \multirow[b]{2}{*}{ Number } & \multirow[b]{2}{*}{$\begin{array}{l}\text { Hospitalisation } \\
\text { outcome }\end{array}$} & \multirow[b]{2}{*}{$\begin{array}{l}\text { Process of care } \\
\text { (preceding hospitalisation) }\end{array}$} & \multirow[b]{2}{*}{ Accepted } & \multirow[b]{2}{*}{$\begin{array}{l}\text { Overall } \\
\text { score } \\
(\%)\end{array}$} & \multicolumn{4}{|c|}{ Would you expect most health professionals to* } \\
\hline & & & & & $\begin{array}{l}\text { Recognise the } \\
\text { problem in the } \\
\text { process of } \\
\text { care? (\%) }\end{array}$ & $\begin{array}{l}\text { Foresee the potential } \\
\text { for hospitalisation } \\
\text { associated with the } \\
\text { process of care? (\%) }\end{array}$ & $\begin{array}{l}\text { Know how to change } \\
\text { the process of care to } \\
\text { reduce the likelihood } \\
\text { of hospitalisation? (\%) }\end{array}$ & $\begin{array}{l}\text { Be able to change the } \\
\text { process of care to } \\
\text { reduce the likelihood } \\
\text { of hospitalisation? (\%) }\end{array}$ \\
\hline 44 & Hypoglycaemia & $\begin{array}{l}\text { 1. Use of a long-acting oral } \\
\text { hypoglycaemic agent } \\
\text { (glibenclamide or glimepiride) } \\
\text { 2. HbA1c level not monitored in } \\
\text { the previous } 6 \text { months }\end{array}$ & $\mathbf{Y}$ & 95 & 100 & 90 & 95 & 95 \\
\hline 45 & $\begin{array}{l}\text { Hyperglycaemia or } \\
\text { hypoglycaemia }\end{array}$ & $\begin{array}{l}\text { 1. Use of insulin } \\
\text { 2. HbA1c level not monitored in } \\
\text { the previous } 6 \text { months }\end{array}$ & $\mathbf{Y}$ & 91.5 & 100 & 95 & 90 & 81 \\
\hline 46 & $\begin{array}{l}\text { Hyperglycaemia or } \\
\text { hypoglycaemia }\end{array}$ & $\begin{array}{l}\text { 1. Use of insulin or oral } \\
\text { hypoglycaemic medicines } \\
\text { 2. Use of medicines that may } \\
\text { increase or decrease blood } \\
\text { glucose concentration } \\
\text { 3. HbA1c level not monitored in } \\
\text { the previous } 6 \text { months }\end{array}$ & $\mathbf{Y}$ & 76.8 & 88 & 75 & 75 & 69 \\
\hline 47 & Hypoglycaemia & $\begin{array}{l}\text { 1. Use of glibenclamide or } \\
\text { glimepiride } \\
\text { 2. Renal function not monitored in } \\
\text { the previous year }\end{array}$ & $\mathbf{Y}$ & 81.5 & 75 & 75 & 88 & 88 \\
\hline 48 & $\begin{array}{l}\text { Cardiovascular } \\
\text { disease }\end{array}$ & $\begin{array}{l}\text { 1. History of diabetes } \\
\text { 2. Not on lipid lowering drug }\end{array}$ & $\mathbf{Y}$ & 81.8 & 88 & 88 & 88 & 63 \\
\hline
\end{tabular}

Numbers in bold represent those who achieved an average score of $\geq 70 \%$ agreement by the expert panel.

*Percentage of respondents who answered 'Agree' or 'Yes' on the three-point Likert scale.

$\mathrm{AF}$, atrial fibrillation; ARB, angiotensin receptor blocker; $\mathrm{BPH}$, benign prostatic hyperplasia; CHF, congestive heart failure; COPD, chronic obstructive pulmonary disease; GI, gastrointestinal;

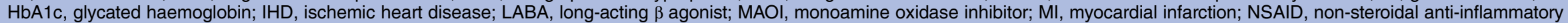

drug; PPI, proton pump inhibitor; SABA, short-acting $\beta$ agonist; SSRI, selective serotonin reuptake inhibitor; TCA, transluminal coronary angioplasty; VTE, venous thromboembolism. 
the supporting evidence base of each developed indicator. In addition, our method for developing the indicators systematically combined the available evidence base with the opinion of clinical experts to develop indicators that are both face and content valid. ${ }^{19}$ The modified RAND method used in our study has been used in indicator development studies previously. ${ }^{18}{ }^{45} \mathrm{~A}$ recent Australian study used this method to validate 657 indicators of healthcare appropriateness. ${ }^{16}$

Our study achieved a $22 \%$ response rate, which is lower than other Australian studies involving medical practitioners, which typically achieve a response rate of around $30 \%{ }^{46-48}$ While this may limit the generalisability of our findings, our results are strengthened by having medical specialists, general practitioners and pharmacists on the expert review panel. ${ }^{44}$ In addition, 78 expert clinicians reviewed the clinical indicators for our study; by comparison, previous studies which developed clinical indicators for preventable medicationrelated hospitalisation used fewer than 20 expert reviewers.

In conclusion, this study has developed a set of face and content validated indicators of medication-related potentially preventable hospitalisations specific for the Australian healthcare setting, linking medication use with suboptimal processes of care resulting in adverse outcomes of hospitalisations. As a measure of health system performance these indicators could identify areas of sub-optimal medication management, particularly at the primary care level, based on routinely collected health administrative health data but with the strong focus on patient outcomes and quality of care rather than processes or quantity.

\section{Author affiliations}

${ }^{1}$ Quality Use of Medicines and Pharmacy Research Centre, Sansom Institute, School of Pharmacy and Medical Sciences, University of South Australia, Adelaide, Australia

${ }^{2}$ School of Pharmacy and Medical Sciences, University of South Australia, Adelaide, Australia

Acknowledgements The authors would like to thank the expert clinical panel and the project advisory group for their time and expertise.

Contributors GEC conceived and designed the study, and was involved in data acquisition, analysis and interpretation, drafted the article and approved the final approval version to be published. LMKE conceived and designed the study, and was involved in data acquisition, analysis and interpretation, critically revised the manuscript for important intellectual content and approved the final approval version to be published. TYW was involved in data acquisition, analysis and interpretation, critically revised the manuscript for important intellectual content and approved the final approval version to be published.

Funding This work was funded by The BUPA Health Foundation

Competing interests None.

Ethics approval Ethics approval for this study was obtained from the University of South Australia's Human Research Ethics Committee.
Provenance and peer review Not commissioned; externally peer reviewed.

Data sharing statement No additional data are available.

Open Access This is an Open Access article distributed in accordance with the Creative Commons Attribution Non Commercial (CC BY-NC 3.0) license, which permits others to distribute, remix, adapt, build upon this work noncommercially, and license their derivative works on different terms, provided the original work is properly cited and the use is non-commercial. See: http:// creativecommons.org/licenses/by-nc/3.0/

\section{REFERENCES}

1. Mainz J. Defining and classifying clinical indicators for quality improvement. Int J Qual Health Care 2003;15:523-30.

2. Robertson $\mathrm{H}$, MacKinnon N. Development of a list of consensus-approved clinical indicators of preventable drug-related morbidity in older adults. Clin Ther 2002;24:1595-613.

3. Bindman A, Grubmach K, Osmond D, et al. Preventable hospitalizations and access to health care. JAMA 1995;274:305-11.

4. Roughead E, Semple S. Medication safety in acute care in Australia: where are we now? Part 1: a review of the extent and causes of medication problems 2002-2008. Aust N Z Health Policy 2009;6:18.

5. Howard R, Avery A, Slavenburg S, et al. Which drugs cause preventable admissions to hospital? A systematic review. $\mathrm{Br} \mathrm{J}$ Clin Pharmacol 2007;63:136-47.

6. MacKinnon N, Hepler C. Preventable drug-related morbidity in older adults. 1. Indicator development. J Manag Care Pharm 2002;8:365-71.

7. Sauer B, Hepler C, Cherney B, et al. Computerized indicators of potential drug-related emergency department and hospital admissions. Am J Manag Care 2007;13:29-35.

8. Morris CJ, Cantrill JA, Hepler CD, et al. Preventing drug-related morbidity-determining valid indicators. Int $J$ Qual Health Care 2002;14:183-98.

9. Mackinnon NJ, Hepler CD. Indicators of preventable drug-related morbidity in older adults 2 . Use within a managed care organization. J Manag Care Pharm 2003;9:134-41.

10. MacKinnon NJ, Hartnell NR, Bowles SK, et al. Incident-event rate of preventable drug-related morbidity in older Adultsin Nova Scotia. Can J Geriatr 2006;9:159-63.

11. Kalisch LM, Caughey GE, Barratt JD, et al. Prevalence of preventable medication-related hospitalizations in Australia: an opportunity to reduce harm. Int J Qual Health Care 2012;24:239-49.

12. Morris C, Cantrill J. Preventing drug-related morbidity-the development of quality indicators. J Clin Pharm Ther 2003;28:295-305

13. Morris C, Cantrill J. Preventable drug-related morbidity indicators in the US and UK. J Manag Care Pharm 2002;8:372-7.

14. Hasson F, Keeney S, McKenna H. Research guidelines for the Delphi survey technique. J Adv Nurs 2000;32:1008-15

15. Keeney S, Hasson F, McKenna H. A critical review of the Delphi technique as a research methodology for nursing. Int $J$ Nurs Stud 2001;38:195-200.

16. Runciman WB, Hunt TD, Hannaford NA, et al. CareTrack: assessing the appropriateness of health care delivery in Australia. Med J Aust 2012;197:100-5.

17. Avery A, Dex G, Mulvaney C, et al. Development of prescribing-safety indicators for GPs using the RAND appropriateness method. Br J Gen Pract 2011;61:e526-e36.

18. Hunt T, Ramanathan S, Hannaford N, et al. CareTrack Australia: assessing the appropriateness of adult healthcare: protocol for a retrospective medical record review. BMJ Open 2012;2:e000665.

19. Teresato AG, Lougheed MD, Gershon AS, et al. Evidence-based performance indicators of primary care for asthma: a modified RAND appropriateness method. Int J Qual Health Care 2010;22:476-85.

20. Australian Government Australian Institute of Health and Welfare (AIHW). Australian Institute of Health and Welfare: National Health Priority Areas. http://www.aihw.gov.au/national-health-priority-areas/ (accessed 17 Mar 2014).

21. Boyce PM, Talley NJ, Burke C, et al. Epidemiology of the functional gastrointestinal disorders diagnosed according to Rome II criteria: an Australian population-based study. Intern Med J 2006;36:28-36.

22. Australian Government National Health and Medical Research Council. NHMRC levels of evidence and grades for recommendations for developers of guidelines 2009. https://www. 
nhmrc.gov.au/ files nhmrc/file/guidelines/developers/nhmrc levels grades_evidence_120423.pdf (accessed 17 Mar 2014).

23. Australian Government Department of Health and Ageing. Schedule of pharmaceutical benefits. http://www.pbs.gov.au/browse/ publications (accessed 17 Mar 2014).

24. Therapeutic Guidelines Limited. Therapeutic guidelines. http://www. tg.org.au/ (accessed 25 Jul 2012).

25. Rossi S. ed Australian medicines handbook. Adelaide: AMH, 2011.

26. National Heart Foundation of Australia and the Cardiac Society of Australia and New Zealand (Chronic Heart Failure Guidelines Expert Writing Panel). Guidelines for the prevention, detection and management of chronic heart failure in Australia. Updated October 2011. http://www.heartfoundation.org.au/SiteCollectionDocuments/ Chronic_Heart_Failure_Guidelines_2011.pdf (accessed 17 Mar 2014).

27. National Heart Foundation of Australia and Cardiac Society of Australia and New Zealand. Reducing risk in heart disease 2007 (updated 2008): Guidelines for preventing cardiovascular events in people with coronary heart disease. http://www.heartfoundation.org. au/SiteCollectionDocuments/Reduce-risk-in-heart-disease-guideline. pdf (accessed 17 Mar 2014).

28. Acute Coronary Syndrome Guidelines Working Group. Guidelines for the management of acute coronary syndromes 2006. Med J Aust 2006;184(8 Suppl):S1-S32.

29. National Heart Foundation (National Blood Pressure Advisory Committee). Hypertension management guide for Doctors National Heart Foundation, 2004

30. National Stroke Foundation. Clinical guidelines for stroke management 2010. Melbourne, Australia. http://strokefoundation. com.au/site/media/clinical_guidelines_stroke_managment_2010_ interactive.pdf (accessed 17 Mar 2014).

31. McKenzie DK, Abramson M, Crockett AJ, et al. The COPD-X Plan: Australian and New Zealand Guidelines for the management of chronic obstructive pulmonary disease V2.30. 2011. http://www. copdx.org.au/home (accessed 17 Mar 2014).

32. National Asthma Council Australia. Asthma management handbook 2006. Melbourne, Australia: National Asthma Council Australia, 2006.

33. Diabetes Australia, Royal Australian College for General Practitioners. Diabetes management in general practice. Guidelines for type 2 diabetes. 16th edn. Diabetes Australia, 2010.

34. Colagiuri S, Dickinson S, Girgis S, et al. National evidence based guideline for blood glucose control in type 2 diabetes. Canberra, Australia: Diabetes Australia and the NHMRC, 2009.

35. Royal Australian College of General Practitioners. Clinical guideline for the prevention and treatment of osteoporosis in postmenopausal women and older men. 2010. http://www.racgp.org.au/download/ documents/Guidelines/Musculoskeletal/racgp_osteo_guideline.pdf (accessed 17 Mar 2014).

36. The Royal Australian College of General Practitioners. Guideline for the non-surgical management of hip and knee osteoarthritis, South Melbourne, Victoria: RACGP, 2009. https://www.nhmrc.gov.au/_ files_nhmrc/publications/attachments/cp117-hip-knee-osteoarthritis. pdf (accessed 17 Mar 2014).

37. Royal Australian and New Zealand College of Psychiatrists Clinical Practice Guidelines Team for Depression. Australian and New Zealand clinical practice guidelines for the treatment of depression. Aus N Z J Psychiatry 2004;38:389-407.

38. Royal Australian and New Zealand College of Psychiatrists Clinical Practice Guidelines Team for Bipolar Disorder. Australian and New Zealand clinical practice guidelines for the treatment of bipolar disorder. Aust N Z J Psychiatry 2004;38:280-305.

39. Australian Governement: National Health and Medical Research Council (NHMRC). NHMRC additional levels of evidence and grades for recommendations for developers of guidelines. http://www.nhmrc. gov.au/_files_nhmrc/file/guidelines/levels_grades05.pdf (accessed 17 Mar 2014)

40. World Health Organization International Classification of Diseases. International statistical classification of diseases and related health problems 10th revision, 2007. http://www.who.int/classifications/ apps/icd/icd10online/ (accessed 8 Aug 2009).

41. Mathers $C D$, Loncar D. Projections of global mortality and burden of disease from 2002 to 2030. PLoS Med 2006;3:e442.

42. Hepler C, Strand L. Opportunities and responsibilities in pharmaceutical care. Am J Hosp Pharm 1990;47:533-43.

43. Australian Institute of Health and Welfare (AIHW). Australian hospital statistics 2010-11. Health services series no 50. Cat. no. HSE 134. Canberra: Australian Government AlHW, 2012. http://www.aihw.gov. au/publication-detail/?id=10737421633 (accessed 17 Mar 2014).

44. Fitch K, Bernstein S, Aguilar M, et al. The RAND/UCLA appropriateness method user's manual. Santa Monica: RAND, 2001.
45. McGlynn E, Asch S, Adams J, et al. The quality of health care delivered to adults in the United States. New Engl J Med 2003;348:2635-45.

46. Bonevski B, Magin P, Horton G, et al. Response rates in GP surveys. Trialling two recruitment strategies. Aust Fam Phys 2011;40:427-30.

47. Britt $\mathrm{H}$, Miller $\mathrm{G}$, Charles J, et al. General practice activity in Australia 2008-09. BEACH: bettering the evaluation and care of health. General Practice Series No. 25. Cat No. GEP 25. Canberra: AlHW, 2009.

48. Johnson C, Lizama N, Garg N, et al. Australian general practitioners' preferences for managing the care of people diagnosed with cancer. Asia Pac J Clin Oncol 2012; doi: 10.1111/ajco.12047

49. Scott PA, Kingsley GH, Scott DL. Non-steroidal anti-inflammatory drugs and cardiac failure: meta-analyses of observational studies and randomised controlled trials. Eur J Heart Fail 2008:10:1102-7.

50. Nissen SE, Wolski K. Effect of rosiglitazone on the risk of myocardial infarction and death from cardiovascular causes. $N$ Engl J Med 2007:356:2457-71.

51. Hunt SA, Abraham WT, Chin MH, et al. ACC/AHA 2005 guideline update for the diagnosis and management of chronic heart failure in the adult: a report of the American College of Cardiology/American Heart Association Task Force on Practice Guidelines (Writing Committee to Update the 2001 Guidelines for the Evaluation and Management of Heart Failure): developed in collaboration with the American College of Chest Physicians and the International Society for Heart and Lung Transplantation: endorsed by the Heart Rhythm Society. Circulation 2005;112:e154-235.

52. Mosca L, Grady D, Barrett-Connor E, et al. Effect of raloxifene on stroke and venous thromboembolism according to subgroups in postmenopausal women at increased risk of coronary heart disease. Stroke 2009;40:147-55.

53. Han L, McCusker J, Cole M, et al. Use of medications with anticholinergic effect predicts clinical severity of delirium symptoms in older medical inpatients. Arch Intern Med 2001:161:1099-105.

54. Edwards JG, Anderson I. Systematic review and guide to selection of selective serotonin reuptake inhibitors. Drugs 1999;57:507-33.

55. Centre for Allied Health Evidence; NHMRC, Department of Health and Ageing. Systematic literature review on the detection, diagnosis, management and prevention of glaucoma. Canberra, Australia: Australian Government, National Health and Medical Research Council, 2009.

56. Gross PA, Hermogenes AW, Sacks HS, et al. The efficacy of influenza vaccine in elderly persons. A meta-analysis and review of the literature. Ann Intern Med 1995;123:518-27.

57. Australian Government. Department of Health and Ageing. NHMRC. The Australian immunisation handbook. 9th edn. Canberra, Australia: Commonwealth of Australia, 2009.

58. Griffin MR, Zhu Y, Moore MR, et al. U.S. hospitalizations for pneumonia after a decade of pneumococcal vaccination. New Engl $J$ Med 2013;369:155-63.

59. Macintyre PE, Scott DA, Visser EJ, et al. Working group of the Australian and, New Zealand College of Anaesthetists and Faculty of Pain Medicine. Acute pain management: scientific evidence. 3rd edn. Melbourne: ANZCA \& FPM, 2010.

60. Herbison P, Hay-Smith J, Ellis G, et al. Effectiveness of anticholinergic drugs compared with placebo in the treatment of overactive bladder: systematic review. BMJ 2003;326:841.

61. McNicol E, Horowicz-Mehler N, Fisk RA, et al. Management of opioid side effects in cancer-related and chronic noncancer pain: a systematic review. J Pain 2003;4:231-56.

62. Wang WH, Huang JQ, Zheng GF, et al. Effects of proton-pump inhibitors on functional dyspepsia: a meta-analysis of randomized placebo-controlled trials. Clin Gastroenterol Hepatol 2007;5:178-85.

63. Moayyedi P, Deeks J, Talley NJ, et al. An update of the Cochrane systematic review of Helicobacter pylori eradication therapy in nonulcer dyspepsia: resolving the discrepancy between systematic reviews. Am J Gastroenterol 2003:98:2621-6.

64. Laine L, Smith R, Min K, et al. Systematic review: the lower gastrointestinal adverse effects of non-steroidal anti-inflammatory drugs. Aliment Pharmacol Ther 2006;24:751-67.

65. Lloyd Jones M, Wilkinson A. Adverse effects and persistence with therapy in patients taking oral alendronate, etidronate or risedronate: a systematic review. The National Institute for Clinical Excellence, 2006.

66. Kanis JA, Johansson $\mathrm{H}$, Oden $\mathrm{A}$, et al. A Meta-analysis of prior corticosteroid use and fracture risk. $J$ Bone Mineral Res 2004;19:893-9.

67. Hartikainen S, Lönnroos E, Louhivuori K. Medication as a risk factor for falls: critical systematic review. J Gerontol Series A Biol Sci Med Sci 2007:62:1172-81. 
68. Gheorghiade M, van Veldhuisen DJ, et al. Contemporary use of digoxin in the management of cardiovascular disorders. Circulation 2006;113:2556-64.

69. Kallas M, Green F, Hewison M, et al. Rare causes of calcitriol-mediated hypercalcemia: a case report and literature review. J Clin Endocrinol Metabol 2010;95:3111-17.

70. Chadban S HM, Twigg S, Thomas M, et al. National evidence based guideline for diagnosis, prevention and management of chronic kidney disease in type 2 diabetes. Canberra, Australia. http://
diabetesaustralia.com.au/PageFiles/763/Chronic\%20Kidney\% 20Disease\%20Guideline\%20August\%202009.pdf (accessed 17 Mar 2014).

71. Diabetes Australia Guideline Development Consortium; Australian Centre for Diabetes Strategies. National evidence based guidelines for the management of type 2 diabetes mellitus. Part 7 lipid control in type 2 diabetes. Australian Centre for Diabetes Strategies. http:// www.nhmrc.gov.au/publications/synopses/di7todi13syn.htm (accessed 17 Mar 2014) 